\title{
From socialisation to internalisation: Cultivating technological pedagogical content knowledge through problem-based learning
}

\author{
Meng Yew Tee and Shuh Shing Lee \\ University of Malaya
}

\begin{abstract}
Recent studies on technology have shifted from the emphasis on technology skills alone to integrating pedagogy and content with technology - what Mishra and Koehler (2005) call technological pedagogical content knowledge (TPACK). Deeper understanding on how TPACK can be cultivated is needed. This design-based research explored how an improvised, problem-based learning approach guided by the SECI framework (socialisation, externalisation, combination, internalisation) can help in-service teachers to cultivate TPACK. Data were collected via self-progress surveys, reflections by the in-service teachers, student produced artifacts, records of overall course design, and log entries by the instructor. Based on the survey data, teachers believed that they had developed TPACK. By comparing the qualitative data from two groups, it was discovered that teachers became better positioned to use TPACK more fruitfully after their mental models moved towards Biggs's Level 2 and 3 approaches in teaching. The course created critical but safe opportunities for teachers to better understand that technology in itself is not likely to improve ineffective teaching practices; and, in selecting technology, teachers may have to reevaluate their teaching practices and to rethink the nature of the subject that they teach.
\end{abstract}

\section{Introduction}

Training teachers solely on how to use a specific technology is not likely to improve the practice of teaching and learning (Brand, 1997; Moursund \& Bielefeldt, 1999; Fulton, Glenn \& Valdez, 2003; Mishra \& Koehler, 2005; So \& Kim, 2009; Lock \& Redmond, 2010). What is needed is an approach that helps teachers learn how to choose, apply, evaluate and further develop different configurations of tools and artifacts - digital and otherwise - depending on their practice, their learners, the contexts they are in, and the nature of the subject they teach. If this sounds like teaching our teachers how to fish, it is. They should not be given a prescribed technology or the proverbial fish; instead, they must learn how to fish, or specifically to think through, critically choose or design and configure, learn and apply technologies that will best meet the teaching and learning needs that exist within their context. If this can be done, teachers can go beyond thinking of themselves as merely being passive consumers of technological tools and begin thinking of themselves as being designers or purposeful users of technology specifically to aid students' learning.

Koehler and Mishra (2005) proposed a framework to address this problem. They argued that good teaching with technology requires understanding the mutual 
relationship between technological, pedagogical and content knowledge (TPACK) to develop appropriate, context-specific strategies and representations. However, there is still much room for research on how TPACK can be cultivated to benefit teachers and students. Initial evidence suggests that successful approaches have involved providing in-service teachers and pre-service teachers with real experiences dealing with educational problems to be solved by technology (Koehler \& Mishra, 2005; Ma, O'Toole \& Keppell, 2008; Guzey \& Roehrig, 2009; So \& Kim, 2009; Hu \& Fyfe, 2010).

Further understanding about how TPACK can be cultivated is needed. This is what this study set out to do. This study reports on the first cycle of a design based research for designing, implementing and refining a course to help in-service teachers cultivate technological, pedagogical and content knowledge (Mishra and Koehler, 2006).

\section{Cultivating TPACK through problem solving approaches}

Mishra and Koehler's (2006) technological, pedagogical and content knowledge (TPACK) is represented by three intersecting circles. At the intersection where the transactional relationship between content, pedagogy, and technology comes together, it is suggested that good teaching with technology requires understanding the mutually reinforcing relationships between all three elements taken together to develop appropriate, context specific strategies and representations (Koehler \& Mishra, 2005).

Briefly, content (C), is the subject matter that is to be learned. Technology (T), broadly encompasses standard technologies such as books and blackboard, as well as more advanced technologies such as Internet and digital video. Pedagogy $(\mathrm{P})$ includes the process and practice or methods of teaching and learning, including the purposes(s), values, techniques or methods used to teach, and strategies for evaluating student learning. The connection and interactions between these three elements are vital. For instance, pedagogical content knowledge (PCK) - initially conceived by Shulman $(1986,1987)$ - combines knowledge of pedagogy in specific content areas. This can be seen in teachers who are able to use a graph (pedagogy) to help students understand the concept of slope (content). However, PCK is not merely utilising certain strategies for certain content. It has to be also capable of answering how well that particular strategy is useful to facilitate students' understanding.

Ultimately, the overlapping of the three elements ( $\mathrm{T}, \mathrm{P}$ and $\mathrm{C})$ results in Technological Pedagogical Content Knowledge. Koehler and Mishra (2007) explained that good teaching with technology for a given content is complex and multidimensional. It requires a nuanced understanding of how a combination of certain technologies and pedagogical technique can make learning of a particular content area more meaningful.

In the context of cultivating TPACK, the basic idea is to create opportunities for teachers to focus on a problem of practice, and then seek ways to critically choose and use technology to address the problem (Savin-Baden, 2000; Hmelo-Silver, 2007; Ma, O'Toole \& Keppell, 2008; So \& Kim, 2009; Hu \& Fyfe, 2010). In this process, they not only learn about technology, they also learn "how to learn" about technology and "how to think" about technology that is most appropriate to the situation they are in, particularly to help engage students towards intended learning outcomes (Biggs, 1999; Koehler \& Mishra, 2005; Kolodner, 2003). 


\section{Design framework}

In this study, an improvised problem-based learning (PBL) approach was utilised. It was PBL in that it was based on a real world, complex problem, solved through a combination of collaborative, iterative and self directed activities (Hmelo-Silver, 2007).

Table 1: Key design considerations for creating activities and conditions to facilitate socialisation, externalisation, combination and internalisation

\begin{tabular}{|c|c|}
\hline Process & Activities and conditions \\
\hline $\begin{array}{l}\text { Socialisation } \\
\text { (S) }\end{array}$ & $\begin{array}{l}\text { Design open-ended activities such as open discussions, inquiries or } \\
\text { explorations. } \\
\text { Create conditions to facilitate sharing of feelings, emotions, } \\
\text { experiences, and mental models. The overall ethos tends to be less } \\
\text { formal and the stakes lower, allowing room for the development of } \\
\text { trusts and rapport. } \\
\text { Examples: Open ended, in class discussions at every session and } \\
\text { asynchronous online discussions. }\end{array}$ \\
\hline $\begin{array}{l}\text { Externalisation } \\
\text { (E) }\end{array}$ & $\begin{array}{l}\text { Design "externalising" activities such as individual and group } \\
\text { writing exercises, model or prototype development, dialogue and } \\
\text { group reflections. } \\
\text { Create conditions to facilitate negotiation and development of } \\
\text { common terms, concepts and meanings. The overall ethos is more } \\
\text { formal than socialisation (but not to the level of combination), with } \\
\text { the stakes increasing (i.e. more concerned with 'do-ability'). } \\
\text { Examples: Individual written reflections, each group's ongoing } \\
\text { writing of a chapter for a wiki-based book, experimenting with } \\
\text { prototype solutions. }\end{array}$ \\
\hline $\begin{array}{l}\text { Combination } \\
\text { (C) }\end{array}$ & $\begin{array}{l}\text { Design authentic or simulated complex situations that challenges } \\
\text { learners to synthesise multiple knowledge bases. } \\
\text { Create conditions to facilitate the organisation and application of } \\
\text { varied knowledge bases more deliberately and systematically. The } \\
\text { overall ethos is most formal and the stakes highest, as the } \\
\text { culmination of knowledge is prepared for application or a more } \\
\text { public consumption. } \\
\text { Examples: Each group synthesising and finalising their chapter in the } \\
\text { wiki-based book; final presentation and sharing; making their } \\
\text { decision on the best possible solution. }\end{array}$ \\
\hline $\begin{array}{l}\text { Internalisation } \\
\text { (I) }\end{array}$ & $\begin{array}{l}\text { Design activities that require action and reflection. } \\
\text { Create conditions to facilitate action and reflection. The overall ethos } \\
\text { varies, as the primary focus is on attaining individual or group } \\
\text { insights or deep understandings. } \\
\text { Examples: Frequent written and oral reflections; implementations of } \\
\text { prototypical/final solution. }\end{array}$ \\
\hline
\end{tabular}

The first aspect of improvisation was the use of guided instruction, in the form of selected readings, mini lectures, and recommended approaches for dealing with the problems (Savin-Baden, 2000; Hmelo-Silver, 2007). Improvisations were made because of the larger number of students $(\mathrm{N}=24)$ and also to scaffold the PBL process for students who have never or rarely engaged in such learning activities. For similar 
reasons, Bransford and Steins' (2002) IDEAL model was used to guide the classroom planning and management process. The IDEAL problem solving process consists of five primary components: Identify problems and opportunities; define goals; explore possible strategies; anticipate outcomes and act; and look back and learn.

The second and perhaps the more important aspect of improvisation is the design of the overall milieu and activities of the course using Nonaka and his colleagues' SECI model of knowledge creation (Takeuchi \& Nonaka, 2004; Nonaka \& Nishiguchi, 2001; Nonaka, Toyama \& Konno, 2000; Nonaka \& Takeuchi, 1995). As summarised in Table 1 , the design is based on the understanding that knowledge - both explicit and tacit - can be actively cultivated and manifested in a shared context that enables knowledge sharing, construction and utilisation through socialisation, externalisation, combination and internalisation (Nonaka \& Takeuchi, 1995; Tee \& Karney, 2010). The overall condition, or $b a$ as Nonaka calls it, was designed to energise the knowledge sharing and cultivating activities by providing enabling conditions of autonomy, fluctuation and creative chaos, redundancy, requisite variety, and trust and commitment (Nonaka, Toyama \& Konno, 2000; Tee \& Karney, 2009).

As such, the intent of this study is to develop a deeper understanding of how an improvised problem-based learning (iPBL) approach implemented in the context of the SECI framework can help cultivate TPACK. Specifically, the study was guided by the following research questions: Can iPBL help in-service teachers cultivate TPACK? If yes, how? If no, why not?

\section{Research context}

\section{Course context}

The students enrolled in this 14-week course on technology in teaching and learning as a core subject in the masters in instructional technology program, or as an elective for several other masters program in the School of Education. The students of this course comprised of 24 in-service teachers, with their ages ranging from mid-20s to early 40s. They taught at elementary, secondary and tertiary levels, in varying subjects including language arts (English language, Malay language, and Chinese language), social sciences (history and business), and mathematics. Twenty-two of the twenty-four participants were women. All of them have been teachers for at least one year, with an average of eight years experience.

\section{Course design}

The initial design for the course was quite straightforward, roughly divided into four chronological segments. The first 4-week segment was to give students time to provide some context and definition to the problems, directly from what they were facing in their real life teaching context. The problem had to be directly related to teaching and learning (in contrast to say, policy or management issues or purely technical problems). The problem had to be complex, as opposed to being too simplistic (for example, 'the LCD projector in my classroom is unreliable'). The problem preferably had to be common or similar to what is being faced by at least two other people. The students worked in teams based on the specific problems they chose to own and work on. 
The second 4-week segment was for the teams to consider different solutions, and then to propose and select a solution. The third 4-week segment was for each group to implement the selected solution in a pilot or full-blown situation, and subject it to further evaluation. The fourth and final 2-week segment was for students to present and discuss the process and outcome of the entire learning cycle.

Throughout the semester, approximately two of the three hours of each class session was used to share findings and suggest and justify ways forward; and the remaining time were mostly given for collaborative meetings. The latter proved important as students found it difficult to find common times to meet outside class due to professional and personal obligations. Each group was required to write a chapter in an electronic book (e-book) project using a wiki-based web site to chronicle their ongoing experience during the course. In addition, they were also requested to write a two to three page reflection every four weeks on what they have learnt during the process.

As mentioned earlier, an improvised problem-based learning (PBL) approach together with the SECI framework was used (see also Table 1). Five articles - including two articles on TPACK (Mishra \& Koehler, 2006; Koehler \& Mishra, 2005) - and two videos, including the "Did you know?" video made by Fisch and McLeod (2009), were selected for focused consideration. Mini lectures and reflections by the instructor were given on an as needed basis, the longest one - which occurred only once during midsemester - went for approximately 45 minutes and the shorter ones - which occurred throughout the semester - lasted just for a few minutes. Students were asked to consider each step rigorously using Bransford and Steins' (2002) IDEAL model and using Mishra and Koehler's (2006) TPACK as a lens.

Very little direct instruction about particular technologies was given, though the instructor offered on numerous occasions to bring in an expert in the event that no one in class had the appropriate knowledge. Moodle was used as a course management platform, and Wikispaces was used as the primary platform for the collaborative e-book project (Zorko, 2009).

\section{Method}

This research was conducted using the design-based research process. The research context - in this case, the course - was subject to an iterative process of designing, developing, implementing, testing, investigating and refining (Barab \& Squire, 2004; Hakkarainen, 2009). The design of the overall learning environment was based on guiding proto-theories in the form of a PBL model improvised with the SECI framework for knowledge creation, as discussed earlier in this paper (Design-Based Research Collective [DBRC], 2003; Wang \& Hannafin, 2005). This was the first of several iterative cycles of design and implementation to create opportunities to collect data to support subsequent designs based on multiple methods of analysis (DBRC, 2003; Edelson, 2002; Wang \& Hannafin, 2005).

In this regard, five types of data were collected, namely: self progress surveys; learning reflections by the participants; progressing draft and final versions of the writings and discussions in the wiki-based e-book; documents, records and artifacts that reflect the overall design of the course; and, log entries written by the instructor (who is also the first author of this paper and the principal investigator for this study). The self 
progress survey initially developed by Schmidt et al (2009) - with Cronbach's alpha for each knowledge domain measuring between .75 and .85 - was utilised to gain an indicator of the participants' own beliefs about their abilities to teach with technology as a result of the experience of going through the course (Shin et al, 2009). The responses - on a Likert scale of 1 to 5 - were analysed using repeated measures $t$ test.

The qualitative data were coded and analysed iteratively based on saliency and saturation (Glaser \& Strauss, 1967; Lincoln \& Guba, 1985). In this study, credibility was addressed with four techniques: triangulation, prolonged engagement, persistent observation, and referential adequacy (Lincoln \& Guba, 1985; Skrtic, 1985). The use of triangulation (Lincoln \& Guba, 1985; Patton, 1990) was particularly important to detect tacit aspects of TPACK. In terms of referential adequacy, all data analysed were captured and documented in its original form. In addition, the data were coded by two coders until consensus was reached.

\section{Discussion of findings}

This section will begin with the reporting and discussion of the results from the self progress survey the participants filled out at the end of the course. This will, in part, address the first research question i.e. can iPBL help in-service teachers cultivate TPACK. Deeper analysis was further done with the qualitative data collected, to investigate the follow up questions i.e. if yes, how? If no, why not? In this regard, the discussion will revolve around two groups that had more salient data in relation to the research questions - Group Mat and Group Ed. Group Mat consisted of five in-service Mathematics teachers: M1 taught at elementary level; M2, M3, and M5 at secondary level; and, M4 at post-secondary level. The problem they identified revolved around M1's Year 5 students who were struggling with fractions. Group Ed consisted of three in-service teachers: E1, E2 and E3. This group chose to work on a problem based on a task given by their principal to help their fellow colleagues to learn to teach with technology.

\section{Self progress survey}

The results of the repeated measures t-tests - as presented in Table 2 - showed that students' understanding of the relationships between technology and content (TCK), the relationship between technology and pedagogy (TPK), and the relationship between technology, pedagogy and content (TPACK), all improved over time. The effect sizes, as measured by Cohen's $d$, were all large - more than 0.8 . In other words, the inter-related areas of $\mathrm{T}, \mathrm{P}$, and $\mathrm{C}$ knowledge areas showed strong progress from before to after the course. While unexpected, it seemed to make sense that students' knowledge about the interaction between pedagogy and content (PCK) changed too. As discussed later in this paper, qualitative data revealed that students seriously reconsidered their pedagogical practices as well as the nature of the subject they taught.

Given that the course is about practical applications of technology in teaching and learning, this finding was encouraging. Teachers enrolled in the course cultivated deeper knowledge of how technology related to other aspects of teaching, specifically content and pedagogy. 
Table 2: Summary statistics of teachers' beliefs in using technology for teaching

\begin{tabular}{|c|c|c|c|c|}
\hline & $\begin{array}{c}\text { Mean } \\
\text { prior }\end{array}$ & $\begin{array}{c}\text { Mean } \\
\text { after }\end{array}$ & $\begin{array}{c}\text { Mean } \\
\text { difference }\end{array}$ & Cohen's $d$ \\
\hline TK & 3.43 & 3.70 & $0.27^{*}$ & 0.74 \\
\hline PK & 3.38 & 4.00 & $0.62^{*}$ & 1.34 \\
\hline CK & 3.51 & 3.82 & $0.31^{*}$ & 0.73 \\
\hline TCK & 3.00 & 4.00 & $1.00^{*}$ & 1.32 \\
\hline TPK & 3.16 & 4.55 & $1.39^{*}$ & 1.18 \\
\hline PCK & 3.23 & 3.86 & $0.63^{*}$ & 1.09 \\
\hline TPACK & 2.98 & 4.07 & $1.09^{*}$ & 1.75 \\
\hline
\end{tabular}

However, it was surprising that the change in technological knowledge (TK) by itself was low (0.31) compared to the rest. The effect size was almost as low as content knowledge $(\mathrm{CK})$ at 0.74 . Group Mat scores even indicated a slight decrease in technology knowledge (see Table 3). Based on the qualitative data, there may be two possible explanations. First, the explicit awareness about their indirect learning of technology in it of itself was not as high. Second, the course was designed to emphasise how technology can be used more effectively in relation to the intended learning outcomes (content knowledge), pedagogical practices of the teacher (pedagogical knowledge), and how students are responding to the culmination of these components in the classroom. As a result, some of teachers learned to repurpose technologies that they already knew how to operate. For example, Group Mat used online math games that required little learning of technology but required major changes in pedagogical practices. Another member of the group already had been using Wikispaces for a year but not with students - so for this individual, learning a new technology in a traditional sense may not have seemed to materialise.

As presented in Table 3, the remaining Group Mat and Ed statistics are not vastly different than the whole class.

Table 3: Mean score prior and after the course for Mat and Ed Groups

\begin{tabular}{|l|c|c|c|c|c|c|c|c|c|c|c|c|c|c|}
\hline & \multicolumn{10}{|c|}{ Mat Group $(\mathrm{n}=5)$} & \multicolumn{6}{c|}{ Ed Group (n = 3) } \\
\cline { 2 - 14 } & TPACK & TPK & TCK & PCK & PK & CK & TK & TPACK & TPK & TCK & PCK & PK & CK & TK \\
\hline $\begin{array}{l}\text { Mean score } \\
\text { before }\end{array}$ & 3.26 & 3.37 & 3.60 & 3.40 & 3.43 & 3.93 & 3.80 & 2.94 & 3.20 & 2.00 & 2.67 & 3.58 & 2.67 & 3.06 \\
\hline Mean score after & 4.21 & 4.52 & 4.40 & 4.20 & 4.03 & 4.33 & 3.66 & 3.61 & 4.13 & 2.67 & 2.33 & 2.88 & 2.77 & 3.33 \\
\hline Mean difference & 0.95 & 1.15 & 0.80 & 0.80 & 0.61 & 0.40 & -0.14 & 0.67 & 0.93 & 0.67 & 0.34 & 0.70 & 0.10 & 0.27 \\
\hline
\end{tabular}

\section{Problem identification: Blame the students}

In the first 4 weeks of the course, as the teachers talked about the problems they faced in their classrooms, one theme was quite resounding: students were at fault for the limited learning that was taking place.

Group Mat talked repeatedly about students who were uninterested, lazy and who had short term memory. Many came from families of low socio-economic status and low levels of education, and thus gained little or no help from the parents. Group Mat reported this in their e-book: 
They always forget what they have learned, and (the) teacher always has to remind them and sometimes re-teach the topic. Sometimes (the) teacher felt that the students lack motivation and always wait(ed) for (the) teacher to give them input. They don't go (seek) for themselves to find out (or clarify) what they don't understand.

Group Ed had similar expressions of frustrations. They were fresh from attempting to teach their colleagues how to use wikis. They were frustrated by the fact that their colleagues were quite uninterested and even those who were somewhat interested, lacked basic knowledge such as knowing how to use email or how collaborative software, or collaboration in itself, can facilitate better learning.

In other words, there was a strong feeling that these were just the way the students were. They either could learn, or could not learn. This is what Biggs (1999) refers to as "blame the students" - or Level 1 - approach to teaching. This was prevalent throughout the writings, rhetoric and the ethos early in the course.

As described in Table 1, it is believed that this openness and honesty in discussions was enabled by design through facilitation of the socialisation process supported by a conducive, low stakes and informal milieu - mostly in the form of in class discussions at every session and asynchronous online discussions (Tee \& Karney, 2009).

\section{Problem definition: Maybe it is the teacher's fault}

At this point, the problem faced by each group was quite clear. Group Mat reported that a majority of M1's students still did not understand fractions. In fact, in a recent assessment, the average score was $38 \%$ with a majority of students failing. None received an "A."

Group Ed reported that their colleagues didn't just struggle with learning how wiki works. They didn't even know how to begin, with a number of them needing help to sign up for an email account. At the Week 4 learning audit, for example, E3 reported that "engaging the digital immigrants" (i.e. their colleagues) was "not an easy-at-all task."

What was not clear was the root causes to the problem. Could the problems be broken down further? For both the groups, the frustration was mounting, as reflected by M3's reflection:

Initially, I felt bored and nervous when we kept discussing the real basis of the problem and root cause. Almost every week, our group will have to present. (Translated)

M2, in her reflections, alluded to the tendencies that most had: "Whenever I encountered any problem, I tend to find the answer and solution straight away."

However, when pushed by questions during in class discussions, Group Mat moved to engage in deeper analysis of the students' background (socioeconomic status, prior achievement and knowledge, and attitude), the context (school ethos, facilities, and students homes) and the subject itself (what was the major stumbling block in learning fractions?).

At first we believe(d) that the problem lay with the students. Our perception was: students are not bright, lazy, no motivation and always playing during class. Using 
TPACK concept makes us realise that we have to look at the situation from different areas. The areas are our knowledge of Mathematics, the content of teaching, the pedagogical practices used in teaching Mathematics, and the technology integration in teaching. (From Group Mat's e-book entry)

At this juncture, the ethos of "blaming the students" began to change. M1 wrote, in her reflections:

While searching for root cause, questions played frequently in my mind: Why is it difficult for students to understand certain concepts? Is it caused by students

themselves or should teachers consider changing the teaching and learning practices? (Translated)

E1 from Group Ed also began reflecting about similar changes in thinking: "I was wrong about many of my students. I always thought, it only takes them self discipline and desire to learn." This is what Biggs (1999) refers to as "what the teacher does" approach of teaching, or Level 2. Biggs also pointed out that this is still a "deficit" model in that the blame is on the teacher. As a team however, Group Ed never quite got to the deep level of analysis of Group Mat. They still leaned towards attributing the root of the problem to their colleagues' mindset and their own failure to use more engaging pedagogical approaches.

The continuing socialisation process in a largely low stakes environment (see Table 1) created additional opportunities for the students in the course to externalise and evaluate basic assumptions and consider opportunities from different angles (Tee \& Karney, 2009).

\section{Defining goals and exploring possible strategies}

About mid-way through the course, students were becoming openly 'arntsy' about the technology aspect of the course. Aren't we here, after all, to learn about technology for teaching and learning? M4 wrote in her reflections:

After attending a few classes, I told my group that I think I should not be in this class since I just want to learn technology and not interested to know how to apply technology in my teaching.

Furthermore, there was real concern about the technology infrastructure that was available to their students whether at school or at home. In fact, the Internet connection to the schools' computer lab - that is, when it was available - was inconsistent. And most students came from homes without computers, or Internet connection.

Still, Group Mat forged ahead. They set goals to find the best ways to help students understand the underlying concepts of fraction by using whatever means possible to engage the students cognitively and help them connect their learning to their daily lives. As the goals became more explicit, what roles technology could play too became clearer. M2 wrote in her reflections:

While teaching, I do not have many opportunities to find other pedagogical techniques in teaching Mathematics. I came to realise that my pedagogical practices should be geared toward providing my students with variety (or a rich) learning environment... I should utilise technology in order to increase students' understanding. 
M3 too begin to express similar understandings:

In order to solve problems faced by the Year 5 students, we found out that it is closely related to students' (lack of foundational) understanding of the content, (and partly because) instruction was not student-centered. It was only after this that we looked for technology-based method to help solve the problems. (Translated)

Here, M2 and M3 began to demonstrate an understanding that introducing technologies without reviewing the interrelating aspects which include pedagogy and content can lead to a naught. They seemed to be developing both an explicit and tacit understanding of the complex interplay between the three basic components of knowledge (content, pedagogical and technological) - basically, the need to teach content through the appropriate use of pedagogical methods with complementing technologies so that learning outcomes can be achieved (Mishra \& Koehler). This is what Biggs (1999) refers to as "what the student does" approach of teaching, or Level 3 , where the focus is on using teaching-learning activities to help students attain the desired depth of understanding. In other words, the focus is on what students learn.

In this regard, Group Ed was somewhat mired in a mode of technical rationality. M2, somewhat uncharacteristically, wrote in her reflections a critique of Group Ed's approach:

Sometimes I felt that teachers (can) overuse or abuse the use of technology in teaching.

We can get in the habit of using it because it's there. For example, when Group Ed said that they want to use Wikispaces eventually in encouraging their colleagues to use technology, I was wondering whether the group was (too) anxious to introduce Wikispaces.

$\mathrm{E} 2$, in his own reflections earlier on, basically arrived at the same conclusion:

We taught Wikispaces on request from the school (authorities) and conducted it in only one session. There were no follow up activities. They (colleagues) dropped out (from the class) and our project failed. (Translated)

As technology took centre stage without deeper deliberation about its relationship with pedagogy and content, Group Ed never quite made full progress towards Bigg's Level 2 and 3 approaches to teaching.

At this point, much of the facilitation of the course was still focused on the externalisation process as stakes increased through feedback from interacting with a real world problem (see Table 1). This continued to create opportunities for the students in the course to explore and challenge new ideas and approaches, and potentially consider the synthesis of new ones (Tee \& Karney, 2009).

\section{Anticipating outcomes and looking back to learn}

Later, Group Ed began to reevaluate their situation. Are their students ready to learn? Is the intended learning outcome within their zone of proximal development? Do the learners have a conceptual understanding of why and how the content can be applied? E1 reflected in hindsight:

I wanted to teach learners about wiki and Internet, but these are very distant from learners' experiences and expectation. Learners might be able to follow step by step to create an account for blogs or wikis but abandoned them right after the course .... 
E1's colleagues continued to resist using the wiki and blog technology for teaching and learning. Many just couldn't see the point. Later, in going back to the drawing boards, Group Ed found a different approach. They concluded that their colleagues were uninterested and unmotivated because they did not see any personal or professional value in the content being taught. So, they went about discovering other ways to stimulate their interest:

(Later, I learned that) they wanted so much to upload their photo in the cyber world, and fell in love with Facebook afterwards. (Now,) sending email is a piece of cake.

As they developed an interest by experiencing the affordances of more relevant technologies, their colleagues began to open their minds about the possibility of teaching with different technologies. Group Ed, at this point, began to discuss the idea of forming small communities to discuss how different technologies can support learning in the subject that each of them taught.

Towards the end of the course, Group Ed wrote in the e-book:

There are various teaching and learning models. Before applying any, we must remember that the "leading character" is always the learner. It is possible for some learning strategies to affect some learners and some learning outcomes but not others. We must understand our learners first before we are able to integrate technology with pedagogy and content effectively.

E3 wrote in an impromptu in class reflection, that:

... (it) has helped me in asking the right questions while designing a lesson plan and while conducting a class itself, such as: Is this method of using this technology meeting the (intended) learning outcomes?

These data suggest that members of Group Ed were moving towards Biggs's Level 2 and 3 approaches to teaching, and thus, became better positioned to use TPACK more fruitfully.

As for Group Mat, the initial deep analysis of their problem and later rigorous planning and iterative approach to conceiving the best solution possible led to clearer indicators of TPACK. In their e-book, they wrote:

\begin{abstract}
The implementation phase has been done quite successfully. (The) teacher managed to attract (the) students' attention to learn fraction. The activities have created excitement not only for the students but also to the teacher herself as learning fraction using technology has never been done before in that class. The students are participative and engaged themselves in the learning part throughout the session. The teacher is quite excited to see the improvement in terms of student understanding of fraction.
\end{abstract}

They also reported that average marks had increased to $68 \%$ from $38 \%$ before the intervention was implemented. In addition, they also reported improvement in students' attitude towards learning mathematics: 97\% were very interested to learn math, compared to $83 \%$ before intervention; $81 \%$ said they had no difficulty learning math, compared to $36 \%$ before intervention; and, $85 \%$ reported that they know how to convert a mixed number to an improper fraction, compared to $33 \%$ before intervention. 
M1 concluded with the following notes at the end of the e-book:

When technologies come (together) with pedagogy and content, it makes teaching and learning more meaningful and interesting. This can be seen by the change in mindset of the students.... especially (towards) fraction (which in the past were) difficult (for them) to learn. I also learned that I should not underestimate my students.

Through the continuation of socialisation and externalising, together with more intensive combination activities during the second half of the course made their learning - both successes and failures - more visible and subject to greater scrutiny and feedback (see Table 1). And as they implemented their solutions, they acted on their plans in a real world setting, and the feedback from the real world setting, their fellow classmates and the instructor made it a fertile ground for individual and collective reflection (see Table 1).

The internalisation seemed to be quite profound. In the final reflection, the instructor wrote:

In the final session, each group reported what they had done. I had invited a number of people to be part of the audience (to increase the stakes a little and to send a message that their work is meaningful outside of this class). Some of the guests were former colleagues of mine who taught at a nearby college. Unbeknownst to me, during the break, they had circled one of the students to ask her more about her project. As she talked and shared about her experiences, I was told later, that tears began to role down her cheeks. The experience had changed her views about teaching mathematics with technology, and specifically about how she could be more effective with underprivileged students. She had thought them lazy and short in memory. This mindset was challenged throughout the course, and as difficult as it was for her, she really appreciated it.

However some challenges continue to exist. Pedagogically, one of the more serious issues was that at least 5 of the 24 individuals took on minimalistic or passive roles during collaborative work, judging by implicit or explicit complains made by group members. From a content perspective, many of the students were frustrated by the fact that technology wasn't taught in a traditional way ("why can't you just teach us a tech tool such as Flash?"). While most discarded this view, it proved to be a distraction for most of the semester. It also suggests that for some of the students, their overall understanding of TPACK may not have fully consolidated. Still, it is worth noting that some 20 different technologies were learned throughout the course, including wiki, blog, video and picture editing tools, and online games. Several tools such as PowerPoint (as students' storytelling tool) and camera video phones (to record students' original limericks to post online for their friends and parents to view) were repurposed to stimulate learning (Mishra \& Koehler, 2007).

\section{Conclusion and implications}

The findings of this study seem to suggest that a PBL-based class designed with a conducive milieu to stimulate socialisation, externalisation, combination and internalisation can help teachers cultivate TPACK (Tables 1 and 2). The in-service teachers demonstrated a more nuanced and intuitive understanding of the complex interplay between the three basic components of knowledge - content, pedagogical and technological (Mishra \& Koehler, 2005). They demonstrated in their discussions 
and implementation of solutions that they needed to use pedagogical methods and technologies in ways that give the students the best opportunities to achieve the intended learning outcomes.

Socialisation and externalisation largely manifested in the form of class discussions and out of class group discussions. Both externalisation and combination can be seen in the wiki based e-book project and higher stakes presentation at the end of the course. Internalisation was stimulated in the implementation and oral reflections in class, and the reflections they were writing for the course. These processes were enabled by an overall milieu that was explicitly designed to encourage autonomy, fluctuation creative chaos, redundancy, requisite variety, trust and commitment (see Table 1; Nonaka \& Takeuchi, 1995; Nonaka, Toyama \& Konno, 2000; Tee \& Karney, $2009,2010)$. Still, a few of the teachers took on passive roles during collaborative work. From the data, it is not clear why this happened. In future studies, the researchers intend to explore this situation further.

An unexpected but welcomed result of this study was the change in the way the teachers viewed teaching and learning. They first started off blaming the students, then themselves, and finally, became more focused on creating a learning experience that can help students achieve the intended learning outcomes (Biggs, 1999). A number of the teachers also came to a profound realisation that technology in itself is not likely to improve ineffective teaching practices. What seems to have happened here is this: as a precursor to learning to choose and use technology, the SECI-based iPBL process had pressed the teachers to re-evaluate their teaching practices and to rethink the nature of the subject that they teach that makes it difficult for students to understand. In this process, the teachers began to re-evaluate old assumptions and this may have opened doors for news ideas to be incorporated in their thinking and practice. Further exploratory studies can be done to look into how such designs can help teachers develop a more reflective practice.

While this study provides important guidance on the cultivation of TPACK, it must be noted that this study is just one preliminary investigation. To be able to extrapolate further, similar studies need to be done in different types of classes involving different demographics. Methodologically, several things may improve the overall design including the use of a pretest-posttest rather than a one time, self progress reflection survey. In the second phase, the researchers also intend to use techniques such as in depth interviews or stimulated recall to get a clearer picture of students' thinking during class or group discussions.

\section{Acknowledgments}

The authors would like to thank the participants for making this study possible as well as the reviewers, whose insightful comments and probing questions greatly improved the quality and readability of this work. This work was funded in part by the University of Malaya Research Grant (UMRG).

\section{References}

Barab, S. \& Squire, K. (2004). Design-based research: Putting a stake in the ground. Journal of the Learning Sciences, 13(1), 1-14. 
Barak, M. \& Dori, Y. J. (2005). Enhancing undergraduate students' chemistry understanding through project-based learning in an IT environment. Science Education, 89(1), 117-139.

Bereiter, C. \& Scardamalia, M. (1993). Surpassing ourselves: An inquiry into the nature and implications of expertise. Chicago: Open Court.

Biggs, J. (1999). Teaching for quality learning at university. Buckingham: Open University Press.

Brand, G. (1997). What research says: Training teachers for using technology. Journal of Staff Development, 19(1), 10-13.

Bransford, J. D. \& Stein, B. S. (2002). Ideal problem solver (2nd ed.). New York: W.H Freeman and Company.

Brown, J. S. \& Duguid, P. (2000). The social life of information. Boston: Harvard Business School Press.

Design-Based Research Collective (2003). Design-based research: An emerging paradigm for educational inquiry. Educational Researcher, 32(1), 5-8.

Edelson, D. C. (2002). Design research: What we learn when we engage in design. Journal of the Learning Sciences, 11(1), 105-122.

Fisch, K. \& McLeod, S. (2009). Did you know? [viewed 8 Jan 2009; verified 21 Feb 2011] http: / / shifthappens.wikispaces.com/

Fulton, K., Glenn, A. \& Valdez, G. (2003). Three preservice programs preparing tomorrow's teachers to use technology: A study to partnerships. [viewed $20 \mathrm{Dec} 2009$, verified $21 \mathrm{Feb}$ 2011] http:/ / www2.learningpt.org/ catalog/item.asp?SessionID=435599375\&productID=246

Glaser, B. G. \& Strauss, A. L. (1967). The discovery of grounded theory: Strategies for qualitative research. Chicago: Aldine Pub. Co.

Guzey, S. S. \& Roehrig, G. H. (2009). Teaching science with technology: Case studies of science teachers' development of technology, pedagogy, and content knowledge. Contemporary Issues in Technology and Teacher Education, 9(1), 25-45. [verified 21 Feb 2011; open access] http: / / www.editlib.org/d/29293/article_29293.pdf

Hakkarainen, P. (2009). Designing and implementing a PBL course on educational digital video production: Lesson learned from a design-based research. Educational Technology Research $\mathcal{E}$ Development, 57(2), 211-228.

Hmelo-Silver, C. (2004). Problem-based learning: What and how do students learn. Educational Psychology Review, 16(3), 235-266.

Hmelo-Silver, C., Duncan, R. G. \& Chinn, C. A. (2007). Scaffolding and achievement in problembased and inquiry learning: A response to Kirschner, Sweller and Clar (2006). Educational Psychologist, 42(2), 99-107

Hu, C. \& Fyfe, V. (2010). Impact of a new curriculum on pre-service teachers' Technical, Pedagogical and Content Knowledge (TPACK). In Curriculum, technology $\mathcal{E}$ transformation for an unknown future. Proceedings ascilite Sydney 2010. http:/ / www.ascilite.org.au/ conferences / sydney $10 /$ Ascilite $\% 20$ conference $\% 20$ proceedings $\% 202010 /$ Chun_Hu-concise.pdf

Koehler, M. J. \& Mishra, P. (2005). Teachers learning technology by design. Journal of Computing in Teacher Education, 21(3), 94-102. 
Koehler, M. J., Mishra, P. \& Yahya, K. (2007). Tracing the development of teacher knowledge in a design seminar: Integrating content, pedagogy and technology. Computers $\mathcal{E}$ Education, 49, 740-762.

Kolodner, J. L., Camp, P. J., Crismond, D., Fasse, B., Gray, J., Holbrook, J., Puntambekar, S. \& Ryan, M. (2003). Problem-based learning meets case-based reasoning in the middle-school science classroom: Putting Learning by Design ${ }^{\mathrm{TM}}$ into practice. Journal of the Learning Sciences, 12(4), 495-547.

Lave, J. \& Wenger, E. (1991). Situated learning: Legitimate peripheral participation. Cambridge; New York: Cambridge University Press.

Lincoln, Y. S. \& Guba, E. G. (1985). Naturalistic inquiry. Beverly Hills, California: Sage Publications.

Lock, J. \& Redmond, P. (2010). Transforming pre-service teacher curriculum: Observation through a TPACK lens. In Curriculum, technology $\mathcal{E}$ transformation for an unknown future. Proceedings ascilite Sydney 2010. http:/ / www.ascilite.org.au/conferences/sydney10/ Ascilite $\% 20$ conference $\% 20$ proceedings $\% 202010 /$ Lock-concise.pdf

Ma, A. K. F., O'Toole, J. M. \& Keppell, M. (2008). An investigation of student teachers' attitudes to the use of media triggered problem based learning. Australasian Journal of Educational Technology, 24(3), 311-325. http:/ / www.ascilite.org.au/ ajet/ ajet24/ma.html

Moursund, D. \& Bielefeldt, T. (1999). Will new teachers be prepared to teach in a digital age? A national survey on information technology in teacher education. Santa Monica, CA: Milken Exchange on Education Technology. [verified 21 Feb 2011; 1.1 MB] http: / / www.eric.ed.gov :80/ERICWebPortal / contentdelivery/ servlet/ ERICServlet?accno=ED428072

Mishra, P. \& Koehler, M. J. (2006). Technological pedagogical content knowledge: A framework for teacher knowledge. Teachers College Record, 108(6), 1017-1054.

Nonaka, I. \& Konno, N. (1998). The concept of "ba": Building a foundation for knowledge creation. California Management Review, 40(Spring), 15.

Nonaka, I. \& Nishiguchi, T. (2001). Knowledge emergence: Social, technical, and evolutionary dimensions of knowledge creation. Oxford: Oxford University Press.

Nonaka, I. \& Takeuchi, H. (1995). The knowledge-creating company: How Japanese companies create the dynamics of innovation. New York: Oxford University Press.

Nonaka, I., Toyama, R. \& Byosiere, P. (2001). A theory of organizational knowledge creation: Understanding the dynamic process of creating knowledge. In M. Dierkes, A. Berthoin Antal, J. Child \& I. Nonaka (Eds.), Handbook of organizational learning and knowledge (pp. 491-517). Oxford: Oxford University Press.

Nonaka, I., Toyama, R. \& Konno, N. (2000, ). SECI, ba and leadership: A unified model of dynamic knowledge creation. Long Range Planning, 33(Feb), 5-34.

Savin-Baden, M. (2000). Problem-based learning in higher education: Untold stories. Buckingham: SHRE and Open University Press.

Schmidt, D., Baran, E., Thompson, A., Koehler, M.J., Mishra, P. \& Shin, T. (2009). Technological pedagogical content knowledge (TPACK): The development and validation of an assessment instrument for preservice teachers. Journal of Research on Technology in Education, 42(2), 123149. [verified 21 Feb 2011] http:/ / www.eric.ed.gov:80/PDFS/EJ868626.pdf 
Shin, T., Koehler, M. J., Mishra, P., Schmidt, D., Baran, E. \& Thompson, A. (2009). Changing technological pedagogical content knowledge (TPACK) through course experiences. Paper presented at the 2009 International Conference of the Society for the Information and Technology \& Teacher Education, 2-6 March, Charleston, South Carolina. [verified 21 Feb 2011] http:/ / punya.educ.msu.edu/publications /Shin_et_al_SITE2009.pdf

Shulman, L. S. (1986). Those who understand: Knowledge growth in teaching. Educational Researcher, 15(2), 4-14.

Shulman, L. S. (1987). Knowledge and teaching: Foundations of the new reform. Harvard Educational Review, 57(1), 1-22.

Skrtic, T. (1985). Doing naturalistic research into education organizations. In Y. S. Lincoln (Ed.), Organization theory and inquiry: The paradigm revolution (pp. 185-220). Beverly Hills: Sage Publications.

So, H.-J. \& Kim, B. (2009). Learning about problem based learning: Student teachers integrating technology, pedagogy and content knowledge. Australasian Journal of Educational Technology, 25(1), 101-116. http:/ / www.ascilite.org.au/ajet/ajet25/ so.html

Takeuchi, H. \& Nonaka, I. (2004). Hitotsubashi on knowledge management. Singapore: John Wiley \& Sons (Asia).

Tee, M.Y. \& Karney, D. (2009). A framework and mental model to foster deep learning in the classroom. In A. Hussain \& N. Idris (Eds), Dimensions of education. New Delhi: Gyan Publishing House, p.293-314.

Tee, M. Y. \& Karney, D. (2010). Sharing and cultivating tacit knowledge in an online learning environment. International Journal of Computer-Supported Collaborative Learning, 5(4), 385-413. [preprint verified 21 Feb 2011]

http:/ / ijcscl.org/download.php?file=tee_karney_5_4.pdf\&path=_preprints / volume5_issue4

Wang, F. \& Hannafin, M. J. (2005). Design-based research and technology-enhanced learning environments. Educational Technology Research \& Development, 53(4), 5-23.

Zorko, V. (2009). Factors affecting the way students collaborate in a wiki for English language learning. Australasian Journal of Educational Technology, 25(5), 645-655.

http: / / www.ascilite.org.au/ajet/ajet25/zorko.html

Dr Tee Meng Yew (contact author)

Department of Curriculum \& Instructional Technology

Faculty of Education, University of Malaya

50603 Kuala Lumpur, Malaysia

Email: mytee@um.edu.my

Shuh Shing Lee, Department of Curriculum \& Instructional Technology

University of Malaya

Please cite as: Tee, M. Y. \& Lee, S. S. (2011). From socialisation to internalisation:

Cultivating technological pedagogical content knowledge through problem-based learning. Australasian Journal of Educational Technology, 27(1), 89-104.

http: / / www.ascilite.org.au/ajet/ajet27/tee.html 